\title{
Forum
}

\section{What Does Collaborative Event Ethnography Tell Us About Global Environmental Governance?}

Rosaleen Duffy

This special issue on collaborative event ethnography (CEE) provides an important contribution to our understanding of global environmental governance (GEG), illustrating the value of ethnographic work to analyze how conventions work, how alliances are formed, and how particular ideas rise to prominence while others are rendered invisible. In this forum, I place the collection of articles in the context of broader debates on the shifting nature of governance in the global system.

In 2000, some years after the publication of Our Global Neighbourhood by the Commission on Global Governance (1995), Craig Murphy wrote that global governance was "poorly done and poorly understood." ${ }^{1}$ In the intervening years global governance has been thoroughly researched and debated, and it has a well-established journal, Global Governance, dedicated to enhancing our understanding of it. Few commentators would contest the idea that global governance exists, or that it denotes a shift in power and authority away from nation-states as the principal global actors towards a system characterized by complex and diverse sites of governance (rather than government). ${ }^{2}$ Few would dispute that international NGOs, nation-states, multilateral organizations, and the private sector have all played leading roles in shaping and establishing global governance. However, there is still much disagreement on how precisely this is manifested in the global system, or over who and what is governed, by what methods, and at what scale. This is evident in debates about the nature of GEG, which is the subject of this special issue of Global Environmental Politics.

Much research and writing on GEG focuses on the "outcomes" or

1. Murphy 2000.

2. Biermann et al 2009; Clapp 2005; Commission on Global Governance 1995; Dingwerth 2008; Dingwerth and Pattberg 2009; Newell 2008, 2012; Newell et al. 2012; Risse 2004; Rosenau and Czempiel 1992; Weiss 2005.

Global Environmental Politics 14:3, August 2014, doi:10.1162/GLEP_a_00242

๑ 2014 by the Massachusetts Institute of Technology

1 LINE SHORT

REGULAR

1 LINE LONG 
126 - What Does Collaborative Event Ethnography Tell Us About Global Environmental Governance?

decisions made at international meetings, or on the structural/global power relations that are embedded in international conventions and institutions, ${ }^{3}$ or on civil society protests around international meetings. ${ }^{4}$ In contrast, these CEEbased analyses allow us to follow discussions within sessions at the Tenth Conference of the Parties (COP10) of the Convention on Biological Diversity (CBD). Via a new methodology, CEE opens up the "black box" of how decisions are made at international fora, how ideas circulate at such meetings, how compromises are made and alliances are formed between different actors; in so doing it offers an original perspective on the debates about GEG. ${ }^{5}$ In the Introduction, the authors argue that CEE enables them to examine how ideas about conservation emerge, gain traction, are contested and debated, and how bargains are struck. From this kind of research we can gain insights into the processes that determine what conservation is, who participates in such processes, and with what consequences. Further, as Corson, Campbell, and MacDonald suggest in this issue, undertaking an ethnography of international conventions contrasts with other approaches to studying GEG; such studies tend to privilege outcome over process and focus on formal state relations, bureaucratic structures, and institutional norms, or embrace path dependency and incrementalism.

CEE enhances our understanding because it offers a more robust and organized methodology, which allows authors to produce more sophisticated analyses of how decisions are made. Rather than relying on participant observation by individual scholars, CEE uses teams of researchers to observe and to take notes, audio recordings, and photographs, which provide a much richer overall picture. In that sense, CEE builds on a strong tradition of participant observation as a research method in international relations, but pushes it forward in an interesting and engaging way.

In essence, as the articles in this special issue show, CEE allows the authors to "focus on the influence of informal relationships, individual agency, situated knowledge, and the construction of hegemonic discourse" (Corson, Campbell, and MacDonald). A good example of this is the article by Campbell, Hagerman, and Gray, who are able to "re-embed" the 2020 targets in their political production during the negotiation stages. The article by Scott et al. is particularly interesting in detailing how and why it was not possible to reach agreements on biofuels, an important analysis that would be missed by a focus on outcomes alone. The special issue is a welcome and original contribution to our understanding of international conventions, because most work on conventions analyzes which agreements were made rather than how they are produced (or not) in the first place.

To explain the additional contribution that this special issue makes to our understanding of GEG, it is useful to link the themes of the articles to broader

1 LINE SHORT

REGULAR

1 LINE LONG
3. Liverman 2004; Newell 2008; Weiss and Wilkinson 2013.

4. Death 2010.

5. O'Neill et al. 2013. 
theoretical debates. There is some general agreement on (expansive and inclusive) definitions of global governance, but there are important differences in how it is understood. Thomas Weiss defines global governance as "the patchwork of formal and informal arrangements among states, international organizations and various public-private partnerships." ${ }^{\circ}$ Biermann et al. see it as composed of organisations, regimes, and other forms of principles, norms, regulations, and decision-making procedures; it is a metalevel of governance, which is located between "regimes" and "world order."7 Bäckstrand captures the ways that global governance is characterized by the participation of multiple actors, arguing that it constitutes a post-sovereign hybrid form of governance; it represents an important form of stakeholder democracy, a type of "participatory multilateralism" or "public-private multilateralism."

Differences in the ways global governance is interpreted stem from their very different approaches to understanding world order. Global governance has been described as a de-territorialized regime of power, or "empire," as an extension of state power, or as an updated version of multilateralism. ${ }^{9}$ In contrast, taking an international political economy approach (IPE), global governance is a solidly neoliberal project, aimed at restructuring global politics. ${ }^{10}$ An IPE approach asks what is to be governed (and what is not), who governs and who is governed, how do they govern, on whose behalf, and with what implications; to do this we need to understand how regimes are shaped by wider material discursive and organisational forces. ${ }^{11}$ Taking an IPE approach allows us to analyze whether global environmental governance is an expression of global hegemony. ${ }^{12}$

Debates on global governance are characterized by claims of greater accountability, inclusiveness, deliberativeness, and transparency. ${ }^{13}$ One of the arguments in favor of expanding the range of nonstate actors involved in global decision-making is that increases in levels of participation could open avenues for organizations and representatives drawn from the global South to engage in a meaningful way. ${ }^{14}$ The CBD is a good example of this, because unlike many other global regimes, it does include nonstate actors in its deliberations and decision-making processes. However, in a article about the Convention on the International Trade in Endangered Species, I argued that we need to ask whether including a wider range of actors increases genuine participation in global environmental governance. ${ }^{15}$ This special issue on the CBD allows us to do just that.

The articles in this issue very clearly interlink with understanding of global

6. Weiss 2005, 254.

7. Biermann et al 2009, 15-18.

8. Backstrand 2006; Risse 2004 .

9. E.g., Diehl 2001; Hardt and Negri 2000; Murphy 2000; Young 1994.

10. Overbeek 2010, 696-698; also see Cox 1996; Gill 1998; Elliot 1997; Murphy 2000.

11. Newell 2008, 507; Newell 2012; Liverman 2004

12. Brand and Gorg 2008.

13. Dingwerth and Pattberg 2009, 731-733; Risse 2004.

14. Pattberg 2006; Risse 2004.

15. Duffy 2013.

1 LINE SHORT REGULAR

1 LINE LONG 
128 - What Does Collaborative Event Ethnography Tell Us About Global Environmental Governance?

governance that emphasize global power relations, and claims to greater inclusivity and participation by a wider range of stakeholders. They demonstrate how regulation for the "global good" can actually benefit and privilege powerful actors in the international system, drawing stakeholders in via partnerships to perpetuate systems that represent "business as usual."16 This draws our attention to the ways that GEG can be responsible for extending and deepening global inequality, as illustrated in the article by Kimberly R. Marion Suiseeya. It examines the ways in which concepts of justice that are part of the development of new regulatory forms produced by the $\mathrm{CBD}$ actually constrain the ability to reduce inequality and produce socially just outcomes. As Marion Suiseeya argues, the primary impetus behind the Nagoya Protocol in 2010 was to address the unjust impacts of the global demand for genetic resources on indigenous peoples and local communities. However, after following, noting, recording, and interpreting discussions at the COP10, Marion Suiseeya suggests that a justice metanorm constrains opportunities for justice in global biodiversity governance. Her interpretation of how the Nagoya Protocol developed in discussions at the CBD differs from the more common approach because it does not offer a deconstruction of the official documents and announcements; instead, the use of CEE means we are able to trace the ways ideas develop and travel in meetings before they become official documents and announcements. Further, this offers the opportunity for a deeper understanding of how regulatory mechanisms themselves produce and sustain global inequalities.

This observation connects to another key theme of the articles and of GEG debates more generally: the role of scientific knowledge. While some analysts view scientists as knowledge brokers under conditions of scientific uncertainty, ${ }^{17}$ the articles in this issue by Gray, Gruby, and Campbell on the role of marine protected areas and by Scott et al. on biofuels characterize scientists as important "translators." The use of scientific knowledge by various interest groups can be characterised as what Risse calls "soft steering." Risse argues that nonhierarchical forms of soft steering in global governance are made possible via systems of sanctions and incentives to encourage compliance. Further, soft steering increases the legitimacy of rules and norms via thorough "arguing" to mutually assess the validity of the argument, which is geared towards meeting a reasoned consensus, which in turn provides a legitimating framework for final decisions. ${ }^{18}$

By following specific discussions and the ways that various categories, concepts, and issues are contested within the CBD, the articles also reveal that this is a messy and iterative process. As Compagnon notes, we should not assume that GEG should automatically or spontaneously assume a democratic, egalitarian character; instead, it can produce new forms of inequality and subordination. ${ }^{19}$ In line with this, these articles demonstrate that transnational environmental

1 LINE SHORT

REGULAR

1 LINE LONG
16. Conca 2006; Paterson 2010.

17. Davis Cross 2012; Demeritt 2006; Duffy 2013; Haas 1992; Jasanoff 2006; Litfin 1994.

18. Risse 2004, 296.

19. Compagnon 2010; Dingwerth 2008. 
decision-makers often project the image of a neutral and uncontested science that will produce universally applicable and technically inspired regulations. Yet the empirical detail in the articles themselves reveals that the process by which such universally applicable regulatory mechanisms are established is far from uncontested. In this sense, CEE allows us to get at the story behind international level decision-making.

The articles do speak to existing debates, but they also offer new insights. This is most apparent in the articles that interrogate the role, development, circulation, and extension of certain ideas in environmental governance. This is a somewhat under-researched area, especially in the arena of GEG. It is very difficult to track and establish the degree of influence that ideas have in international decision-making, and studies that do so are the exception rather than the norm. ${ }^{20}$ In this special issue, Campbell, Hagermann, and Gray analyze the role of targets in GEG, arguing that they matter because they are highly visible, easily communicated objects for political and technical action, with potentially wideranging impacts. Targets define and reinforce a particular vision of conservation and how it should be accomplished, and targets reinforce the role of science in the CBD's work. It is difficult to strip out the role and power of ideas from their wider context, including the power relations of the various actors promoting or opposing them, but this article provides a convincing analysis of that. Equally, the article by Corson, Campbell, and MacDonald is an excellent example of how CEE can help us understand the power of ideas, how they travel over time and space. These authors review how their "markets" team charted the development and rise of the economics of ecosystems and biodiversity (TEEB) across three CEEs: the World Conservation Congress, CBD COP10, and Rio+20. All were critical sites for TEEB's institutionalization in GEG, so that by the time it reached COP10 in 2010 it was a central mechanism "employed by the CBD and its supporters to situate biodiversity with the green economy." This provides a rare insight into how certain ideas become hegemonic at the global level, and as such offers an original contribution to our understanding of how GEG operates.

This links with my earlier point about the importance of understanding how GEG might produce new, or deepen existing, global inequalities. Jasanoff argues that science and technology are more likely to increase the power of metropolitan centers and possibly re-inscribe unequal distributions of wealth and privilege. $^{21}$

To conclude, these articles speak to and reinforce important parts of the debate on GEG; they firmly support an IPE approach, as well as the need to understand how regulations can reflect and/or deepen existing global inequalities, the power of epistemic communities, and the role of ideas. However, they offer a novel take on an increasingly well-researched arena; by using ethnography, the authors offer a fascinating insight into the dynamics of international

20. Mirowski and Plehwe 2009.

21. Jasanoff 2006, 273-277; Demerrit 2006.

1 LINE SHORT

REGULAR

1 LINE LONG 
130 - What Does Collaborative Event Ethnography Tell Us About Global Environmental Governance?

conventions and the CBD in particular. What we need now are more CEEs to uncover and critically interrogate how global conventions work, how alliances are forged, how particular ideas come to the fore, and how others are silenced.

\section{References}

Bäckstrand, Karin. 2006. Democratising Global Environmental Governance? Stakeholder Democracy after the World Summit on Sustainable Development. European Journal of International Relations 12 (4): 467-498.

Biermann, Frank, Philipp Pattberg, Harro Van Asselt, and Fariborz Zelli. 2009. The Fragmentation of Global Governance Architectures: A Framework for Analysis. Global Environmental Politics 9 (4): 14-40.

Brand, Ulrich, and Christoph Gorg. 2008. "Post Fordist Governance of Nature: The Internationalisation of the State and the Case of Genetic Resources-A NeoPoulantzian Perspective. Review of International Political Economy 15 (4): 567-589.

Cammack, Paul. 2005. The Governance of Global Capitalism: A New Materialist Perspective. Historical Materialism 11 (2): 61-74.

Clapp, Jennifer. 2005. Global Environmental Governance for Corporate Responsibility and Accountability. Global Environmental Politics 5 (3): 23-34.

Commission on Global Governance. 1995. Our Global Neighbourhood. Oxford, UK: Oxford University Press.

Compagnon, Daniel. 2010. Global Governance and the South: Blind Spot or Terra Incognita? International Studies Review 12 (4): 710-715.

Conca, Ken. 2006. Governing Water: Contentious Transnational Politics and Global Institution Building. Cambridge, MA: MIT Press.

Davis Cross, Mai'a. 2012. Rethinking Epistemic Communities Twenty Years Later. Review of International Studies 39 (1): 137-160.

Cox, Robert. 1996. Approaches to World Order. Cambridge, UK: Cambridge University Press.

Death, Carl. 2010. Troubles at the Top: South African Protests and the 2002 Johannesburg Summit. African Affairs 109 (437): 555-574.

Demerritt, David. 2006. Science Studies, Climate Change and the Prospects for a Constructivist Critique. Economy and Society 35 (3): 453-479.

Diehl, Paul, ed. 2001. The Politics of Global Governance: International Organizations in a Changing World. Boulder, CO: Lynne Rienner.

Dingwerth, Klaus. 2008. Private Transnational Governance and the Developing World: A Comparative Perspective. International Studies Quarterly 52 (3): 607-634.

Dingwerth, Klaus, and Philipp Pattberg. 2009. World Politics and Organizational Fields: The Case of Transnational Sustainability Governance. European Journal of International Relations 15 (4): 707-744.

Duffy, Rosaleen. 2013. Global Environmental Governance and North-South Dynamics: The Case of CITES. Environment and Planning C: Government and Policy 31(2): 222239.

Elliot, Lorraine. 2007. Transnational Environmental Crime in the Asia Pacific: An Un(Der)-Securitised Security Problem? The Pacific Review 20 (4): 499-522.

1 LINE SHORT

REGULAR

1 LINE LONG
Gill, Stephen. 1998. New Constitutionalism, Democratisation and Global Political Economy. Pacifica Review 10 (1): 23-38. 
Haas, Peter, M. 1992. Epistemic Communities and International Policy Coordination. International Organization 46 (1): 1-35.

Hardt, Michael, and Antonio Negri. 2000. Empire. Cambrdge MA: Harvard University Press.

Jasanoff, Sheila. 2006. Biotechnology and Empire: The Global Power of Seeds and Science. Osiris 21 (1): 273-292.

Litfin, Karen. 1994. Ozone Discourses: Science and Politics in Global Environmental Cooperation. New York, NY: Columbia University Press.

Liverman, Diana. 2004. Who Governs, at What Scale and at What Price? Geography, Environmental Governance, and the Commodification of Nature. Annals of the Association of American Geographers 94 (4): 734-738.

Mirowski, Philip, and Dieter Plehwe. 2009. The Road from Mount Pelerin: The Making of a Neoliberal Thought Collective. Cambridge, MA: Harvard University.

Murphy, Craig. 2000. Global Governance: Poorly Done and Poorly Understood. International Affairs 76 (4): 789-804.

Newell, Peter. 2008. The Political Economy of Global Environmental Governance. Review of International Studies 34 (3): 507-529.

Newell, Peter. 2012. Globalization and the Environment: Capitalism, Ecology and Power. Cambridge, UK: Polity.

O'Neill, Kate, Erika Weinthal, Kimberley R. Marion Suiseeya, Steven Bernstein, Avery Cohn, Michael W. Stone, and Benjamin Cashore. 2013. Methods and Global Environmental Governance. Annual Review of Environment and Resources, 38 (1): $441-$ 471.

Overbeek, Henk. 2010. Global Governance: From Radical Transformation to Neo-Liberal Management. International Studies Review 12 (4): 696-702.

Paterson, Matthew. 2010. Legitimation and Accumulation in Climate Change Governance. New Political Economy 15: 345-368.

Pattberg, Philipp. 2006. Private Governance and the South: Lessons From Global Forest Politics. Third World Quarterly 27 (4): 579-593.

Risse, Thomas. 2004. Global Governance and Communicative Action. Government and Opposition 39 (2): 288-313.

Rosenau, James N., and Ernst O. Czempiel. 1992. Governance Without Government: Order and Change in World Politics. Cambridge, UK: Cambridge University Press.

Weiss, Thomas G. 2005. Governance, Good Governance and Global Governance: Conceptual and Actual Challenges. In The Global Governance Reader, edited by Rorden Wilkinson, 68-88. London, UK: Routledge.

Weiss, Thomas G., and Rorden Wilkinson. 2013. International Organization and Global Governance. London, UK: Routledge.

Young, Oran. 1994. International Governance: Protecting the Environment in a Stateless Society. Ithaca, NY: Cornell University Press. 
132 - What Does Collaborative Event Ethnography Tell Us About Global Environmental Governance? 